\author{
ОМФАЦИТОВЫЙ ПАРАДОКС В ПЕРИДОТИТАХ МАНТИИ \\ М.Ю. Шур ${ }^{1}$, А.Л. Перчук ${ }^{1,2}$ \\ ${ }^{1}$ Московский государственный университет им. М.В. Ломоносова, \\ 119234, Москва, Ленинские горы, 1, Россия \\ ${ }^{2}$ Институт экспериментальной минералогии РАН, \\ 142432, Черноголовка, Московская обл., ул. Институтская, 4, Россия
}

\begin{abstract}
Омфацит, являясь типоморфным минералом эклогитов, совершенно не свойствен ассоциациям перидотитов. Тем не менее находки этого минерала во включениях в перидотитовых алмазах могут рассматриваться как косвенное свидетельство в пользу существования этой парадоксальной минеральной ассоциации. Представлены результаты экспериментов по взаимодействию между карбонатсодержащим амфиболитом и оливином, моделирующих процессы, происходящие между корой и мантией в зонах субдукции. Эксперименты показывают, что при 2.9 ГПа и $850-900{ }^{\circ} \mathrm{C}$ на границе областей сегрегации кислого расплава с перидотитовым субстратом происходит рост омфацита, ассоциирующего либо с гранатом и ортопироксеном, либо с флогопитом. Омфацит в опытах имеет только реакционно-магматическую природу и не образуется метасоматическим путем. В свете полученных экспериментальных данных обсуждаются находки омфацита во включениях в алмазах перидотитового парагенезиса, а также в некоторых пироксенитах из кимберлитов.
\end{abstract}

Омфацит, перидотит, эклогит, субдукиия, мантия.

\title{
OMPHACITE PARADOX IN MANTLE PERIDOTITES
}

\section{M.Yu. Shur and A.L. Perchuk}

Omphacite is a typomorphic mineral of eclogites, which is inappropriate to mineral assemblages of peridotites. Nevertheless, findings of this mineral in inclusions in peridotitic diamonds can be considered as indirect evidence for the existence of this paradoxical mineral assemblage. In this paper we present experimental results on the interaction between carbonate-bearing amphibolite and olivine that model processes operated at the crust-mantle boundary in subduction zones. The experiments demonstrate growth of omphacite at the interface between acid melt and peridotite media at $2.9 \mathrm{GPa}$ and $850-900{ }^{\circ} \mathrm{C}$; the omphacite coexists either with garnet and orthopyroxene or with phlogopite. The synthetic omphacite is exclusively of reactive-magmatic origin and does not form in metasomatic way. Findings of omphacite inclusions in peridotitic diamonds and in some pyroxenites from kimberlites are discussed in scope of the obtained experimental data.

Omphacite, peridotite, eclogite, subduction, mantle

\section{ВВЕДЕНИЕ}

Фрагменты вещества верхней мантии, наблюдаемые на поверхности в офиолитовых комплексах, массивах альпинотипных перидотитов [Савельева, 1987; Nicolas, Christensen, 1987; Krogh, Carswell, 1995; Bodinier, Godard, 2003] и ксенолитах в кимберлитах и базальтах [Соболев, 1974; Fountain, Christensen 1989; Pearson et al., 2003; Arai, Ishimaru, 2008] свидетельствуют о том, что верхняя мантия сложена эклогитами, пироксенитами и перидотитами, с существенным преобладанием последних. Отличительной особенностью минерального состава эклогитов от других пород мантии является присутствие омфацита - клинопироксена с содержанием жадеитовой молекулы $\left(\mathrm{NaAlSi}_{2} \mathrm{O}_{6}\right)$ более 20 мол. \%. Рост омфацита в перидотитах маловероятен в силу небольшого содержания в их валовом химическом составе натрия, а в дунитах еще и алюминия. И, действительно, о находках омфацитсодержащих перидотитов, насколько нам известно, до сих пор не сообщалось. Клинопироксены с широкими вариациями содержаний примесей $\mathrm{Na}_{2} \mathrm{O}$ (1.53-5.96 мас. \%), $\mathrm{Cr}_{2} \mathrm{O}_{3}$ (1.77-4.23 мас. \%) и $\mathrm{Al}_{2} \mathrm{O}_{3}(0.99-5.53$ мас. \%), существенно превышающих ранее установленные, были недавно обнаружены во включениях в ксенокристах лерцолитового оливина из кимберлита тр. Удачная-Восточная, Якутия [Соболев и др., 2015]. Однако даже в этих клинопироксенах содержание жадеитового минала оказывается ниже порогового уровня для омфацита.

() М.Ю. Шур, А.Л. Перчук ${ }^{\bowtie}, 2015$

凶e-mail: alp@geol.msu.ru

DOI: $10.15372 / G i G 20151105$ 
На фоне колоссального объема фактического материала по составам минералов мантийных перидотитов и эклогитов, а также включений в алмазах [Sobolev et al., 1999; Shirey et al., 2013] сообщения о включениях омфацита в алмазах из перидотитового типа парагенезиса [Соболев и др., 2009] и о включениях омфацита, ассоциирующего с оливином, в алмазах из кимберлитов [Гаранин и др., 1991; Wang, 1998] представляются парадоксальными. По мнению В. Вэнга [Wang, 1998], подобная ассоциация возникла в результате многостадийного процесса, который начинался с роста алмаза в эклогите. Впоследствии эклогит попал под воздействие горячего мантийного плюма и претерпел частичное плавление. В ходе этого процесса алмаз переместился в перидотитовый субстрат, где и продолжил свой рост. O.Г. Сафонов с соавторами [Safonov et al., 2009] придерживаются иной точки зрения, полагая, что перемещения алмаза не происходило, но изменялся состав субстрата. Преобразования контролировались щелочным карбонатно-хлоридным расплавом и водно-хлоридным флюидом, что приводило к перидотизации эклогита.

Омфацит является породообразующим минералом мантийных эклогитов, многие из которых относятся к группе A (классификация по [Coleman et al., 1965]). Генезис этих эклогитов обычно связывается [Добрецов и др., 1989; Carswell, 1990; Jacob, 2004] либо с высокобарным преобразованием метабазитов в субдуцирующих плитах, либо с кумулусным осаждением в глубинных расплавах основного состава. Однако на этом гипотезы образования эклогитов данной группы не исчерпываются. Так, Л. Тэйлор с коллегами [Taylor et al., 2003] на основе геохимических и петрологических данных по ксенолитам эклогитов и гранатовых вебстеритов (с омфацитовым клинопироксеном) из кимберлитовой тр. Обнаженная в Якутии предположили принципиально иной механизм образования эклогитов. По их мнению, мантийные эклогиты могут образовываться при взаимодействии кислых расплавов (ТТГ) и карбонатитов, выделившихся из погружающейся плиты, с деплетированными породами мантийного клина. Свидетельства в пользу этой гипотезы отмечаются в ксенолитах эклогитов из других кимберлитовых трубок [Viljoen et al., 2005; Рагозин и др., 2006; Shatsky et al., 2008].

В настоящей работе приводятся экспериментальные данные, которые раскрывают особенности взаимодействия кислых расплавов с оливином при $P T$-условиях в верхней части океанической плиты в так называемых «горячих» зонах субдукции [Syracuse et al., 2010]. Полученные результаты рассматриваются в контексте появления омфацитсодержащих парагенезисов в ультраосновном субстрате и во включениях в перидотитовых алмазах.

\section{ЭКСПЕРИМЕНТ}

Эксперименты, моделирующие взаимодействие между субдуцирующей плитой и мантией, выполнялись по методике, изложенной в работе [Перчук и др., 2013]. В качестве исходных веществ использовались карбонатсодержащий гранатовый амфиболит (модельный аналог метабазитов субдуцирующей плиты) и кристаллы оливина из дунита (модельный аналог наиболее деплетированных пород мантии; отметим, что основные эффекты, связанные с образованием омфацита, сохраняются и в лерцолитах, и в верлитах (неопубликованные данные авторов)).

Гранатовый амфиболит был отобран из блыбского высокобарного комплекса на Большом Кавказе и состоял из амфибола (65\%), плагиоклаза (15\%), граната (10\%), эпидота (4 \%), кварца (4 \%) и карбоната (2\%), в качестве акцессорных минералов содержал титанит и ильменит [Перчук и др., 2013]. Оливин был отобран в карьере Ахайм (Норвегия), он представлен прозрачными оливково-зелеными кристаллами. Составы исходных веществ приводятся в таблице.

Порошки исходных пород, перетертые до размерности 10-50 мкм (с отдельными зернами до 80 мкм), помещали в платиновые ампулы в виде «сэндвича» - внизу амфиболит, сверху оливин, что обеспечивало восходящую миграцию через оливин флюидов и расплавов, выделяющихся из амфиболита при повышении температуры и давления. Ампулы герметично заваривали лишь снизу, верхний торец был открыт для приближения к природным условиям, где выделившийся из слэба (slab - погруженная в мантию часть субдуцирующей плиты) флюид не циркулирует между слэбом и мантией. Ампулы помещали в соляные ячейки высокого давления, описанные в работе [Перчук и др., 2013].

Опыты проводили на установке цилиндр-поршень в ИЭМ РАН. Ампулы длиной 4 мм и диаметром 3 мм помещали в область ячейки высокого давления, где поддерживался минимальный градиент по температуре (не более $20^{\circ} \mathrm{C}$ на краях ампулы). Фугитивность кислорода в опытах контролировали графитовым нагревателем. В данной работе приводятся результаты двух опытов (Sub55 и Sub73). Они выполнялись при одинаковом давлении (2.9 ГПа) и близкой продолжительности (160 и 164 ч), различалась лишь температура $-850{ }^{\circ} \mathrm{C}$ (оп. Sub55) и $900{ }^{\circ} \mathrm{C}$ (оп. Sub73).

\section{АНАЛИТИЧЕСКИЕ ПРОЦЕДУРЫ}

Электронно-микроскопические исследования и микрозондовые измерения проводили в лаборатории локальных методов исследования вещества кафедры петрологии геологического факультета МГУ 
Представительные анализы* исходных веществ и продуктов опытов Sub55 и Sub73 из реакционных зон на контакте оливина с расплавом

\begin{tabular}{|c|c|c|c|c|c|c|c|c|c|c|c|c|c|c|c|c|}
\hline \multirow{2}{*}{$\begin{array}{c}\text { Компо- } \\
\text { нент }\end{array}$} & \multicolumn{2}{|c|}{$\begin{array}{c}\text { Исходные ве- } \\
\text { щества } \\
\end{array}$} & \multicolumn{8}{|c|}{ Sub55 } & \multicolumn{6}{|c|}{ Sub73 } \\
\hline & $\mathrm{Ol}$ & $\begin{array}{l}\text { Амфи- } \\
\text { болит } \\
\end{array}$ & Omph & Omph & Opx & Opx & Phl & Phl & G & $\mathrm{G}$ & Omph & Omph & $\mathrm{Opx}_{1}$ & Opx & G & G \\
\hline $\begin{array}{l}\mathrm{SiO}_{2}, \\
\text { мас. \% }\end{array}$ & 41.24 & 52.87 & 55.58 & 55.36 & 57.97 & 56.94 & 42.63 & 42.49 & 75.92 & 76.57 & 55.34 & 55.35 & 55.14 & 56.16 & 75.29 & 75.20 \\
\hline $\mathrm{TiO}_{2}$ & 0.00 & 1.15 & 0.13 & 0.30 & 0.03 & 0.06 & 0.43 & 0.57 & 0.14 & 0.11 & 0.48 & 0.58 & 0.03 & 0.10 & 0.28 & 0.37 \\
\hline $\mathrm{Al}_{2} \mathrm{O}_{3}$ & 0.09 & 13.51 & 11.09 & 11.54 & 1.62 & 1.19 & 15.30 & 15.05 & 14.43 & 14.56 & 10.76 & 10.64 & 3.30 & 1.06 & 14.68 & 14.69 \\
\hline $\mathrm{Cr}_{2} \mathrm{O}_{3}$ & 0.03 & $<10_{\Gamma} \Gamma / \mathrm{T}$ & 0.05 & 0.01 & 0.07 & 0.07 & 0.01 & 0.00 & 0.01 & 0.00 & 0.01 & 0.01 & 0.00 & 0.01 & 0.02 & 0.02 \\
\hline $\mathrm{FeO}^{* *}$ & 7.13 & 15.02 & 0.65 & 0.47 & 2.37 & 3.18 & 1.35 & 1.44 & 0.10 & 0.11 & 4.98 & 4.51 & 8.54 & 4.74 & 0.79 & 0.82 \\
\hline $\mathrm{MnO}$ & 0.11 & 0.203 & 0.08 & 0.10 & 0.15 & 0.03 & 0.03 & 0.10 & 0.06 & 0.08 & 0.10 & 0.11 & 0.13 & 0.05 & 0.01 & 0.02 \\
\hline $\mathrm{MgO}$ & 51.33 & 5.15 & 11.66 & 10.92 & 36.74 & 36.65 & 23.21 & 23.23 & 0.28 & 0.50 & 12.22 & 11.10 & 32.52 & 37.07 & 0.58 & 0.56 \\
\hline $\mathrm{CaO}$ & 0.00 & 6.73 & 14.00 & 13.72 & 0.14 & 0.05 & 0.02 & 0.05 & 0.41 & 0.83 & 10.52 & 12.03 & 0.34 & 0.09 & 0.84 & 0.84 \\
\hline $\mathrm{Na}_{2} \mathrm{O}$ & 0.00 & 2.42 & 5.54 & 5.91 & 0.28 & 0.18 & 0.49 & 0.51 & 4.15 & 2.96 & 5.61 & 5.55 & 0.21 & 0.00 & 3.51 & 3.28 \\
\hline $\mathrm{K}_{2} \mathrm{O}$ & 0.00 & 0.36 & 0.06 & 0.07 & \begin{tabular}{|l|}
0.05 \\
\end{tabular} & 0.05 & 9.37 & 9.12 & 4.11 & 3.80 & 0.01 & 0.03 & 0.00 & 0.00 & 4.00 & 4.20 \\
\hline \multirow[t]{2}{*}{ Сумма } & 99.92 & 97.79 & 98.82 & 98.41 & 99.42 & 98.41 & 92.84 & 92.52 & 100.00 & 100.00 & 100.01 & |99.90 & 100.21 & 100.29 & 100.00 & 100.00 \\
\hline & \multicolumn{16}{|c|}{ Кристаллохимическая формула } \\
\hline О, ф.ед. & 4 & - & 6 & 6 & 6 & 6 & 11 & 11 & - & - & 6 & 6 & 6 & 6 & - & - \\
\hline $\mathrm{Si}$ & 1.00 & - & 1.97 & 1.97 & 1.97 & 1.97 & 3.08 & 3.08 & - & - & 1.96 & 1.96 & 1.92 & 1.95 & - & - \\
\hline $\mathrm{Ti}$ & 0.00 & - & 0.00 & 0.01 & 0.00 & 0.00 & 0.02 & 0.03 & - & - & 0.01 & 0.02 & 0.00 & 0.00 & - & - \\
\hline $\mathrm{Al}$ & 0.00 & - & 0.46 & 0.48 & 0.07 & 0.05 & 1.30 & 1.29 & - & - & 0.45 & 0.44 & 0.14 & 0.04 & - & - \\
\hline $\mathrm{Cr}$ & 0.00 & - & 0.00 & 0.00 & 0.00 & 0.00 & 0.00 & 0.00 & - & - & 0.00 & 0.00 & 0.00 & 0.00 & - & - \\
\hline $\mathrm{Fe}^{2+}$ & 0.14 & - & 0.02 & 0.01 & 0.07 & 0.09 & 0.08 & 0.09 & - & - & 0.15 & 0.13 & 0.25 & 0.14 & - & - \\
\hline $\mathrm{Mn}$ & 0.00 & - & 0.00 & 0.00 & 0.00 & 0.00 & 0.00 & 0.01 & - & - & 0.00 & 0.00 & 0.00 & 0.00 & - & - \\
\hline $\mathrm{Mg}$ & 1.85 & - & 0.62 & 0.58 & 1.86 & 1.89 & 2.50 & 2.51 & - & - & 0.64 & 0.59 & 1.69 & 1.89 & - & - \\
\hline $\mathrm{Ca}$ & 0.00 & - & 0.53 & 0.52 & 0.01 & 0.00 & 0.00 & 0.00 & - & - & 0.40 & 0.46 & 0.01 & 0.00 & - & - \\
\hline $\mathrm{Na}$ & 0.00 & - & 0.38 & 0.41 & 0.02 & 0.01 & 0.07 & 0.07 & - & - & 0.38 & 0.38 & 0.01 & 0.00 & - & - \\
\hline $\mathrm{K}$ & 0.00 & - & 0.00 & 0.00 & 0.00 & 0.00 & 0.87 & 0.84 & - & - & 0.00 & 0.00 & 0.00 & 0.00 & - & - \\
\hline Сумма & 3.00 & - & 3.99 & 3.99 & 4.00 & 4.01 & 7.94 & 7.92 & - & - & 4.00 & 3.99 & 4.02 & 4.02 & - & - \\
\hline$X_{\mathrm{Mg}}$ & 0.93 & - & 0.97 & 0.98 & 0.97 & 0.95 & 0.97 & 0.97 & - & - & 0.81 & 0.81 & 0.87 & 0.93 & - & - \\
\hline$X_{\mathrm{Jd}}$ & - & - & 0.38 & 0.1 & - & - & - & - & - & - & 0.38 & 0.38 & - & 一 & - & - \\
\hline
\end{tabular}

Примечание. $\mathrm{G}$ - стекло, $\mathrm{Ol}$ - оливин, Omph - омфацит, Орх - ортопироксен метасоматический, Орх 1 магматический ортопироксен, $\mathrm{Phl}$ - флогопит.

* Микрозондовые анализы, за исключением состава амфиболита, полученного методом РФА (ИГЕМ РАН, аналитик А.И. Якушев).

** $\mathrm{Fe}_{2} \mathrm{O}_{3}$ для амфиболита.

на сканирующем электронном микроскопе Jeol JSM-6480LV с энергодисперсионным спектрометром (ЭДС) X-Max 50 (Oxford Instruments) и на электронно-зондовом микроанализаторе Jeol JXA-8230 Superprobe с пятью волнодисперсионными спектрометрами (ВДС).

Исследования полированных образцов, помещенных в полистироловые шашки, выполнялись в режиме наблюдения высококонтрастного изображения в отраженных электронах. Локальный количественный энергодисперсионный анализ фаз осуществлялся при ускоряющем напряжении 20 кВ и силе тока электронного зонда 0.7 нА. Волновой дифракционный анализ выполнялся при том же напряжении и силе тока зонда 20 нА. Время накопления сигнала на пике каждого элемента составляло $20 \mathrm{c}$, а фона по 10 с с каждой стороны. Для калибровки при ВДС-измерениях и для стандартизации и оптимизации профилей пиков спектральных линий элементов при ЭДС-анализе использованы стандарты соответствующих оксидов и силикатов (их измерения осуществлялись в условиях, идентичных параметрам аналитических определений). Анализы минералов производили в точке, где диаметр области генерации рентгеновского излучения составлял около 3 мкм. Состав стекол анализировался посредством сканирования по площади, чтобы избежать потери щелочных компонентов. Площадь сканирования достигала сотни квадратных микрометров.

Химический состав гранатового амфиболита (см. таблицу) был определен в ИГЕМ РАН (аналитик А.И. Якушев) методом рентгенофлуоресцентной спектрометрии (XRF) на вакуумном спектрометре 
последовательного действия (с дисперсией по длине волны), модель PW2400 производства компании Philips Analytical. Определение потерь при прокаливании (п.п.п.) не выполнялось.

\section{РЕЗУЛЬТАТЫ ОПЫТОВ}

В ампулах после опытов помимо метаморфических преобразований исходных пород возникли две реакционные зоны - по контакту амфиболита и оливина и по контактам оливина с новообразованными кислыми расплавами, поднимающимися вдоль стенок ампул (рис. $1, a$ ).

Гранатовый амфиболит в обоих опытах почти полностью преобразовался в эклогит, сложенный гранатом, омфацитом, фенгитом и $\mathrm{SiO}_{2}$ (присутствие коэсита на Раман-спектрометре не проверялось). Среди исходных минералов амфиболита в продуктах опыта сохранился лишь гранат, но и тот находился в ядрах одноименных кристаллов. Превращение амфиболит $\rightarrow$ эклогит сопровождалось выделением водно-углекислого флюида, вызывающим дегидратационное плавление.

Восходящие потоки флюида и расплава воздействовали на оливиновый слой. В результате в его основании возникла реакционная зона, сложенная ортопироксеном и магнезитом (см. рис. 1, б). Мощность этой зоны составляет 15-30 мкм. Выше реакционной зоны вдоль границ зерен оливина наблюдаются микронные образования ортопироксена и граната, свидетельствующие о привносе $\mathrm{Si}, \mathrm{Al}, \mathrm{Fe}, \mathrm{Ca}$ и других компонентов расплавом (и флюидом?), поднимающимся из метабазитовой части ампулы (анало-
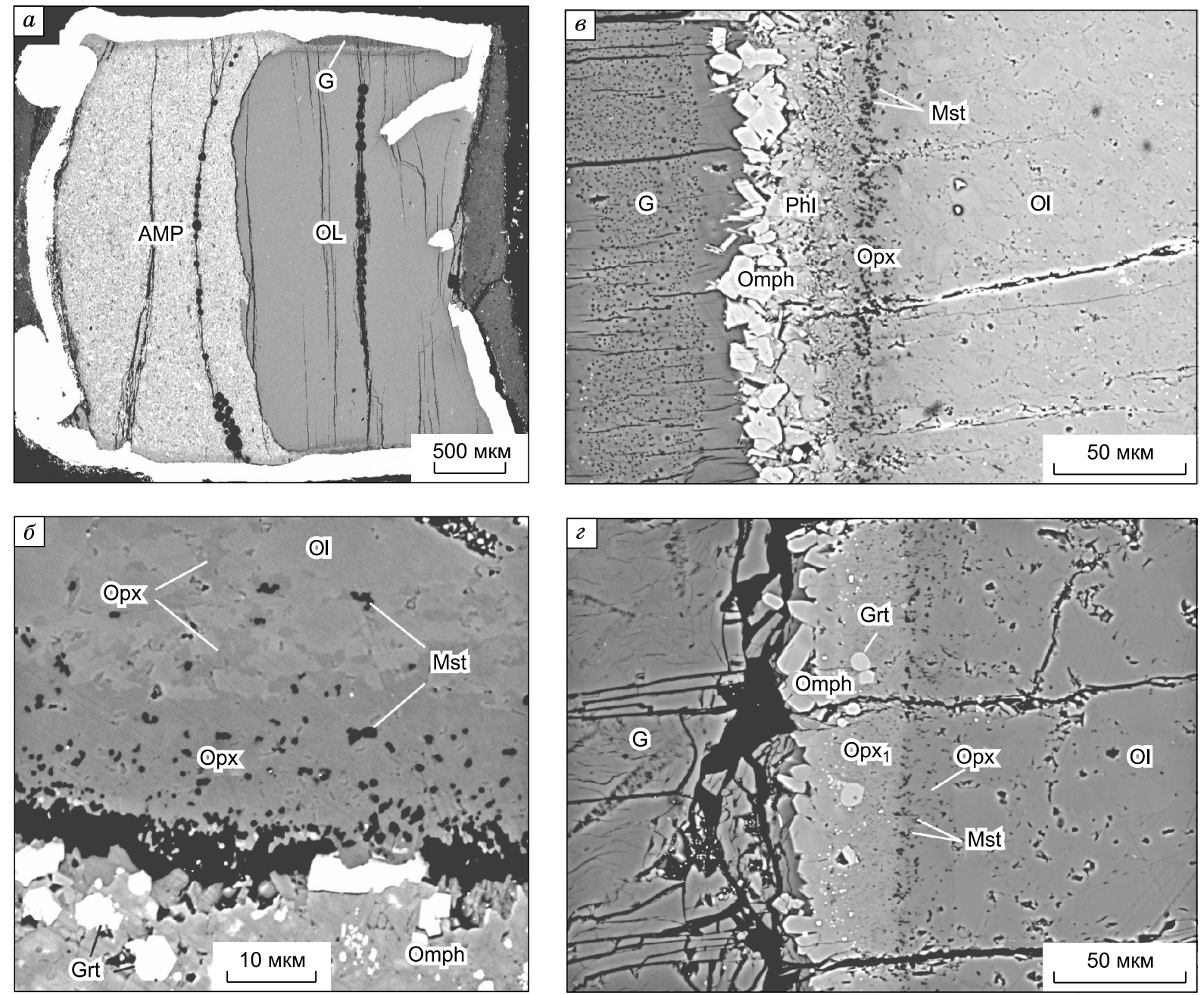

\section{Рис. 1. Микрофотографии продуктов опытов в обратнорассеянных электронах.}

$a$ - вид ампулы после оп. Sub55 при $850^{\circ} \mathrm{C}$ и 2.9 ГПа, отсутствие крышки над оливиновым слоем позволяет флюиду и расплавам покидать ампулу; $\sigma$ - реакционная Орх-Mst зона между амфиболитовым и оливиновым слоями, в оливиновой зоне по границам зерен оливина развивается Opx и Mst, оп. Sub55; в - реакционные структуры на контакте кислого расплава и оливина в оп. Sub55; 2 - реакционные структуры на контакте кислого расплава и оливина в оп. Sub73. Пояса ярких точек во флогопитовой и омфацитовой зонах на рис. (в) и (2) соответственно - переотложенная из стенок ампулы платина. AMP — амфиболитовый слой, OL — оливиновый слой, Grt — гранат, Mst — магнезит. Остальные усл. обозн. см. в таблице. 
гичный, но более масштабный процесс описан в работе [Перчук и др., 2013]). По присутствию спектральных пиков калия в областях с новообразованиями можно предположить о наличии субмикронных пленок стекла (или флогопита). В этих же областях встречаются многочисленные поры, свидетельствующие о существовании флюидной фазы. Обратим внимание, что мы не наблюдали ни в одном из опытов (включая неопубликованные данные) рост клинопироксена при миграции расплава (флюида) по границам зерен перидотитового парагенезиса.

Основной объем расплавов, образованных при частичном плавлении амфиболита, аккумулировался возле стенок в оливиновой зоне в виде выклинивающихся жил с мощностью в основании до 200 мкм (см. рис. 1, в). Такое местоположение расплава, по всей видимости, обусловлено повышенной температурой стенок ампулы по сравнению с шихтой. Отметим также многочисленные пузырьки в центральной части стекол (см. рис. 1, в), указывающие на интенсивное выделение летучих компонентов при закалке расплава.

На контакте между расплавом и оливином отчетливо видна реакционная зона мощностью 50 70 мкм, характер зональности которой зависит от температуры опыта (см. рис. 1, , , г). Контактирующая с расплавом зона в обоих опытах сложена омфацитом, с небольшим количеством флогопита в оп. Sub55. Отметим, что кристаллы омфацита идиоморфные и определенно растут из расплава. Их приуроченность к богатой магнием оливиновой стенке свидетельствует о контактово-реакционном изменении состава расплава в приконтактовой области.

Минеральный состав следующей зоны зависит от температуры опыта. При $850{ }^{\circ} \mathrm{C}$ (Sub55) она сложена кристаллами флогопита с мелкой «сыпью» субмикронных выделений платины (диффузия через расплав из стенок ампулы). Следующая зона сложена ортопироксеном и магнезитом. Ее минеральный состав идентичен реакционной зоне, находящейся между метабазитом и оливином (см. рис. 1, б). По-видимому, ее образование происходило метасоматическим путем, т.е. отлично от близлежащего магматического омфацита.

В более высокотемпературном опыте (Sub73) зона с магматическим омфацитом переходит в ортопироксеновую с редкими кристаллами граната. Последние тяготеют к омфацитовому краю и находятся в горизонте с платиновой «сыпью» (см. рис. 1, 2). Наличие платины, диффундирующей через расплав, указывает на то, что ортопироксен и гранат, так же как и омфацит, могли расти из расплава. А вот следующая магнезит-ортопироксеновая зона, как отмечалось выше, образовывалась метасоматическим путем.

Составы фаз. Составы исходных веществ, а также фаз из реакционных зон, образующихся на контакте расплава с оливином, приведены в таблице. Мы отмечали частичную потерю железа за счет диффузии в стенки ампулы, полагая, что этот эффект не сказывается существенным образом на рассматриваемых процессах. Нормализованные анализы стекол имеют риолитовый состав с суммарным содержанием щелочей $\left(\mathrm{Na}_{2} \mathrm{O}\right.$ и $\left.\mathrm{K}_{2} \mathrm{O}\right)$ около 7 мас. \% при $\mathrm{K}_{2} \mathrm{O} / \mathrm{Na}_{2} \mathrm{O} \approx 1$. В стеклах присутствует хлор (до 0.3 мас. \%). Магматические омфациты содержат от 0.35 до 0.45 мольных долей жадеитового минала при магнезиальности от 0.83 до 0.98. Можно отметить отрицательную корреляцию магнезиальности от температуры. В составе некоторых омфацитов присутствуют небольшие, но значимые (более $2 \sigma$ ) количества $\mathrm{K}_{2} \mathrm{O}$ и $\mathrm{Cr}_{2} \mathrm{O}_{3}$. Флогопиты, ассоциирующие с омфацитом, имеют магнезиальность около 0.97 , содержание $\mathrm{TiO}_{2}$ до 0.6 мас. \% и небольшое количество хлора (0.1 мас. \%), источником которого, вероятно, являлся исходный амфибол. Ортопироксены, сосуществующие с магнезитом (см. рис. 1, в, 2), содержат около 1 мас. $\% \mathrm{Al}_{2} \mathrm{O}_{3}$ при магнезиальности $\sim 0.93$. Их составы заметно отличаются от ортопироксенов, сосуществующих с гранатом; последние более глиноземистые $\left(\mathrm{Al}_{2} \mathrm{O}_{3}\right.$ до 2.8 мас. \%) и менее магнезиальные $\left(X_{\mathrm{Mg}} \approx 0.88\right)$ и потому на изображении в обратнорассеянных электронах они более светлые.

\section{ОБСУЖДЕНИЕ РЕЗУЛЬТАТОВ}

Сравнение составов синтетических и природных омфацитов. Представленные в работе реакционно-магматические омфациты, образованные на границе кислого расплава с дунитом при 2.9 ГПа, конечно же, не могут в точности воспроизвести составы омфацитов, захваченных растущими перидотитовыми алмазами. Связано это как с разными $P T$-условиями формирования (при алмазообразовании в мантии давление более 4 ГПа, а температура более $900{ }^{\circ} \mathrm{C}$ ), так и с возможными вариациями химического состава расплавов и вмещающих перидотитов. Примечательно, однако, что по таким параметрам состава, как $\mathrm{Na}_{2} \mathrm{O}, \mathrm{Al}_{2} \mathrm{O}_{3}$ и $\mathrm{Cr}_{2} \mathrm{O}_{3}$, поля синтетических и природных омфацитов из включений в перидотитовых алмазах перекрываются (рис. 2).

Перекрытие составов менее всего проявлено на диаграммах $\mathrm{Na}_{2} \mathrm{O}-\mathrm{MgO}$ и $\mathrm{Al}_{2} \mathrm{O}_{3}-\mathrm{MgO}$ (см. pис. 2, б, г), где синтетические и природные омфациты образуют параллельные тренды с отрицательным наклоном; при этом синтетические омфациты оказываются в целом более магнезиальными, чем омфациты природные. Следует отметить, что в природных условиях омфацит может (и должен) изменять свой состав после кристаллизации на стенках микроканалов, по которым мигрирует кислый рас- 

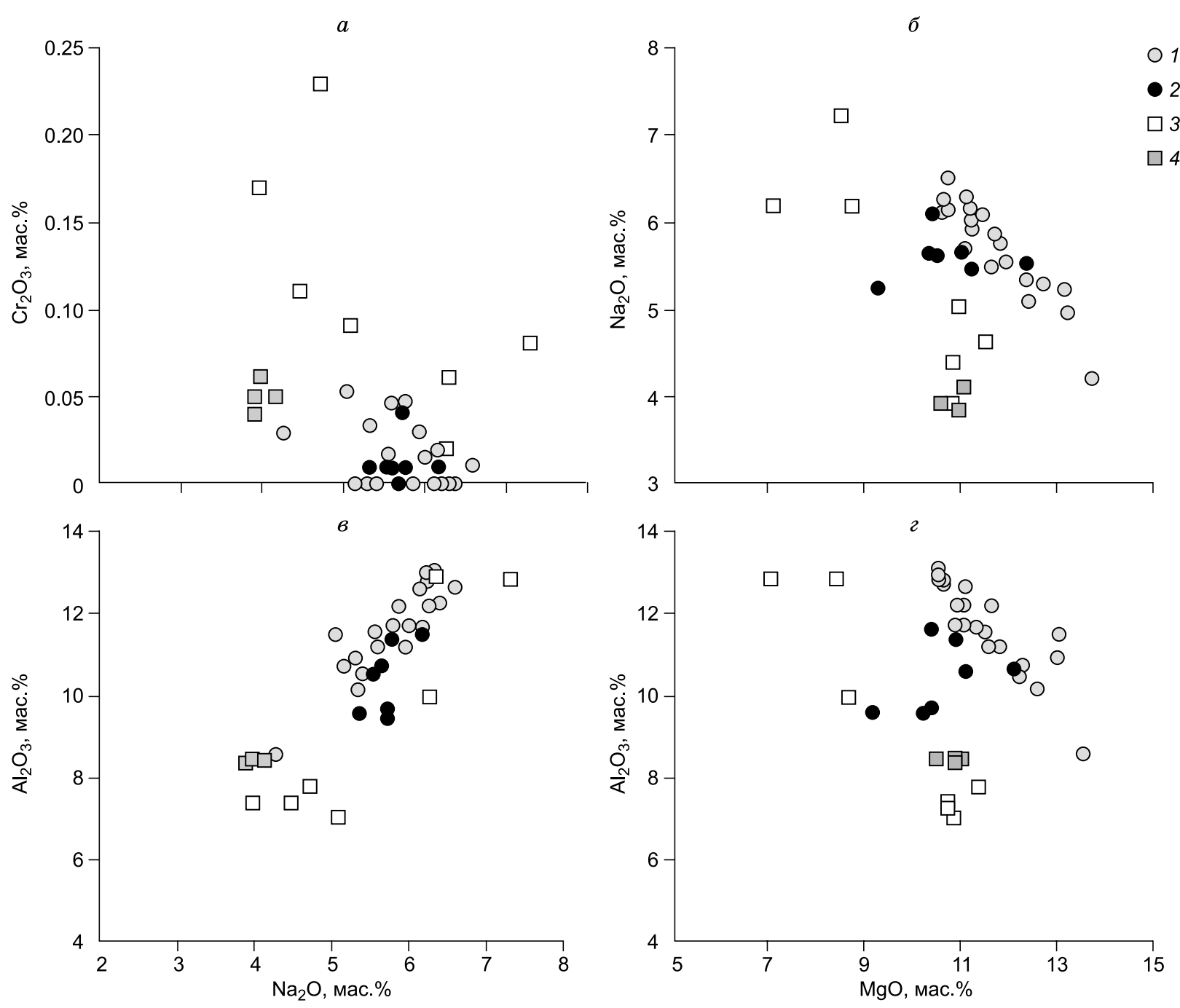

Рис. 2. Параметры состава магматических омфацитов из опытов Sub55 (1) и Sub73 (2) в сравнении с омфацитами из включений в перидотитовых алмазах по данным [Соболев и др., 2009] (3) и [Wang, 1998] (4).

плав. Связано это с тем, что омфацит, возникший по рассматриваемому реакционно-магматическому механизму, первое время может не находиться в термодинамическом равновесии с оливином и/или ортопироксеном.

Омфациты из включений в алмазах, относящихся к перидотитовому парагенезису, являются, как правило, более хромистыми, чем синтетические (см. рис. $2, a$ ). Однако и здесь мы не видим серьезного противоречия с экспериментом. Во-первых, перекрытие полей составов все-таки наблюдается. Во-вторых, несмотря на предельно низкое содержание хрома в исходных оливине $\left(\mathrm{Cr}_{2} \mathrm{O}_{3}=350\right.$ г/т, по данным ICP MS анализа) и амфиболите $\left(\mathrm{Cr}_{2} \mathrm{O}_{3}<10\right.$ г/т, по данным РФА анализа), некоторые реакционно-магматические омфациты из опытов содержат значительно большие количества этого компонента ( $\sim 500$ г/т, см. таблицу), чем исходные вещества. Так как обогащение хромом связано, прежде всего, с перидотитовым субстратом, можно предположить, что при наличии в нем богатых хромом минералов (хромдиопсида, хромшпинелидов), концентрация хрома в омфаците может быть существенно увеличена по сравнению с наблюдаемой в настоящее время. Кроме того, уточним, что далеко не все включения омфацитов в алмазах содержат примесь хрома в значительных количествах [Stachel, Harris, 2008].

Отметим еще один оксид, по которому составы омфацитов перекрываются незначительно, — это $\mathrm{K}_{2} \mathrm{O}$. В омфацитах из включений его содержание варьирует от 0.02 до 0.94 мас. \%, в экспериментальных образцах этот диапазон существенно у́же $(0.00-0.19$ мас. \%). Подобное различие вполне закономерно, так как растворимость в твердом растворе клинопироксена калиевого минала ( $\left.\mathrm{KAlSi}_{2} \mathrm{O}_{6}\right)$ увеличивается 
с ростом давления [Shimizu, 1971; Соболев и др., 1972; Perchuk et al., 2002; Сафонов и др., 2005]. Напомним, что в кислых расплавах, образованных при частичном плавлении метабазита, содержатся достаточные для формирования калийсодержащего пироксена количества $\mathrm{K}_{2} \mathrm{O}$ и $\mathrm{Al}_{2} \mathrm{O}_{3}$ - более 3.5 и 12 мас. \% соответственно (см. таблицу) [Сафонов и др., 2004].

О глубинности образования кислых расплавов в субдуцирующих плитах. Компьютерное моделирование позволяет рассчитывать термальную структуру зон субдукции в зависимости от многочисленных параметров, таких как скорость конвергенции, возраст плит, время субдукции, угол субдукции, место сцепления коры и надсубдукционной мантии, вязкое трение и др. [Peacock et al., 1994; Syracuse et al., 2010; Gerya, 2011]. Объединяя эти данные с фазовыми диаграммами для различных систем (например, базальт-вода, осадок-вода, перидотит-вода), можно получить петрологическую структуру зон субдукции [Schmidt, Poli, 1998; Hacker et al., 2003; Peacock et al., 2005; van Keken et al., 2011]. Фактически при всех неопределенностях подобного подхода появляется возможность судить не только о минеральном парагенезисе в каждом участке зоны субдукции, но и о возможности его плавления.

Процессы плавления в зонах субдукции во многом контролируются водным флюидом, который выделяется при разложении водосодержащих минералов субдуцирующей плиты и отчасти субдукционного канала [Peacock, 1990; Schmidt, Poli, 1998; Tatsumi, 2000; Portnyagin et al., 2007; Grove et al., 2012]. Причем источник флюида может находиться не только в самом слое, где происходит плавление, но и в нижележащих толщах, где в силу специфики термальной структуры создается более низкая температуpa, способствующая сохранению водосодержащих минералов. Например, верхняя часть мантийного разреза субдуцирующей океанической литосферы может сохранять водосодержащие минералы до глубин нижней мантии - 800 км (30 ГПа) [Fumagalli, Poli, 2005; Ohtani, 2005; Литасов, 2011]. В субдуцирющих метабазитах фенгит может сохраняться до глубин более 270 км (9 ГПа) [Poli, Schmidt, 2002; Литасов, 2011]. Водный резервуар в глубинных участках субдуцирующих плит пополняется (поддерживается) за счет «воды» (точнее водорода) в структуре большинства номинально безводных породообразующих минералов [Ohtani, 2005; Smyth, 2006]. Таким образом, погружающиеся плиты, в том числе и на постдуговых (postarc) глубинах (> 140 км), могут содержать значительные объемы водного флюида, необходимого для частичного плавления пород и/или образования в них надкритических флюидов.

Основными источниками кислых расплавов, генерируемых в субдуцирующих плитах, являются метаосадки и метабазиты.

Экспериментальные исследования плавления метапелитов в присутствии водного флюида при $P T$-параметрах зоны субдукции позволили проследить линию водного солидуса, а также составы флюида и расплавов в диапазоне 2.5-4.5 ГПа и 600-1050 ${ }^{\circ} \mathrm{C}$ [Hermann, Spandler, 2008]. На основе этих данных можно говорить о возможности образования кислых расплавов в осадочном слое океанической коры вплоть до $P T$-условий стабильности алмаза. Не исключено, что кислые магмы (или надкритические флюиды) могут выплавляться из метаосадков и на больших глубинах, но соответствующие экспериментальные данные, насколько нам известно, отсутствуют. Вместе с тем опыты по плавлению среднестатистического субдукционного осадка (GLOSS-global subduction sediment) в присутствии водно-углекислого флюида при давлении 7.5-12 ГПа выявили образование не кислых, а карбонатитовых расплавов [Bulatov et al., 2014].

Экспериментальные данные в системе базальт-вода показывают, что $P T$-параметры второй критической точки, при которой исчезает фазовая граница между флюидом и водным расплавом, могут быть разными - 1000-1050 ${ }^{\circ} \mathrm{C}$ при $~ 5.5$ ГПа [Kessel et al., 2005] или $770{ }^{\circ} \mathrm{C}$ при 3.4 ГПа [Mibe et al., 2011]. Указанные различия, вероятно, связаны с использованием в опытах разных исходных веществ. Отметим, что в экспериментах [Kessel et al., 2005] кислые $\left(\mathrm{SiO}_{2}>67\right.$ мас. \%) выплавки из метабазита наблюдаются в широком диапазоне $P T$-условий $\left(800-1100{ }^{\circ} \mathrm{C}\right.$ при 4 ГПа и $800-1200{ }^{\circ} \mathrm{C}$ при 5 ГПа). В работе [Mibe et al., 2011] расплавы имеют среднюю кремнекислотность; правда, измеренные составы отвечают температурам на более чем $200{ }^{\circ} \mathrm{C}$ выше модельных геотерм для «горячих» зон субдукции [Syracuse et al., 2010]. Очевидно, что при более низких (приближенных к реальным) температурах расплавы должны отвечать меньшим степеням плавления, а следовательно, иметь более кислый состав.

Плавление в системе базальт-вода изучалось также при 3.8 ГПа и повышенных температурах ( $T$ выше на $100{ }^{\circ} \mathrm{C}$ самой горячей современной геотермы на поверхности слэба) - $1100-1150{ }^{\circ} \mathrm{C}$ [Rapp et al., 1999]. Частичное плавление гидротермально измененных базальтов в этих опытах приводило к образованию кислых (адакитовых) расплавов, которые мигрировали через перидотиты, метасоматически преобразуя последние. Относительные объемы кислого расплава по сравнению с перидотитом были настолько значительными (отношение расплав/порода $=2 / 1$ и $1 / 1$ ), что перидотит полностью растворялся при метасоматическом процессе. В результате образовывалась гранат-ортопироксеновая (в одном опыте с амфиболом) реакционная зона. Аналогичная реакционная зона отмечается и в наших опытах на границе амфиболита и дунита (см. раздел «Результаты опытов»). Но как отмечалось выше, омфацит в 
этой зоне не образуется, т.е. флюидно-магматические процессы на границах метабазит-перидотит и кислый расплав-перидотит, по всей видимости, отличаются.

Таким образом, экспериментальные данные по плавлению пород слэба и сведения о термальной и петрологической структурах зон субдукции указывают на возможность генерации в слэбах кислых расплавов до глубин 150 км, отвечающих $P T$-условиям стабильности алмаза. Ввиду отсутствия экспериментальных данных в широком диапазоне $P T$-условий, мы не можем утверждать, что при миграции этих расплавов в мантии будет непременно образовываться реакционно-магматический омфацит, но отметим, что поле его термодинамической стабильности и химический состав системы явных противопоказаний этому явлению не дают.

О сегрегации кислых расплавов в мантии. Представленные в этой работе экспериментальные данные показывают, что образование омфацита может происходить лишь локально - на границах обособленных областей (прожилков, микро- и макроочагов) водосодержащей кислой магмы с оливинсодержащим субстратом. О возможности сегрегации кислых расплавов в мантии можно косвенно судить, например, по адакитам. Как известно, адакитовые расплавы ${ }^{1}$ генерируются при частичном плавлении базальтовой (а иногда и осадочной) части разреза океанической коры в зонах субдукции на глубинах более 90 км [Martin et al., 2005; Castillo, 2006; Peacock, Wang, 1999]. Из экспериментов по плавлению амфиболитов и базальтов в присутствии воды [Rapp et al., 1999; Kessel et al., 2005], а также по расплавным включениям в перидотитах [Schiano, 2003; Наумов и др., 2010] следует, что эти расплавы часто имеют кислый состав. В действительности же наряду с кремнекислыми адакитами в природе наблюдаются и разновидности, обедненные кремнеземом [Martin et al., 2005]. Снижение кремнекислотности последних, сопровождаемое повышением содержания в них магния и других компонентов, связано с частичной ассимиляцией перидотитового субстрата поднимающейся кислой магмой. Эксперименты, выполненные со смесью порошков перидотита и тоналита при 1.5 ГПа, показывают [Carroll, Wyllie, 1989], что при 5$10 \%$-й ассимиляции перидотита тоналитовым расплавом ликвидусной фазой является ортопироксен, но по мере его кристаллизации начинают выделяться также гранат и клинопироксен, содержащий, как подчеркивают авторы, в твердом растворе до 10-20\% жадеита и Са молекулы Чермака.

Изменение первичного состава расплава зависит от скорости подъема магмы: чем она выше, тем меньше изменяется состав расплава за счет ассимиляции вмещающих пород. Медленный подъем расплавов в мантии может осуществляться за счет пластического течения пород [Riley et al., 1990; Kohlstedt, Holtzman, 2009] или механизма растворения-переотложения породы в расплаве [Гегузин, Кружанов, 1979; Watson, 1982; Riley, Kohlstedt, 1991; Hammouda, Laporte, 2000; Перчук и др., 2009; Shatskiy et al., 2013]. В первом случае скорость процесса лимитируется твердофазовой диффузией, а во втором - более быстрой диффузией в расплаве. Наличие в мантийном клине конвекции [Davies, Stevenson, 1992; Gerya et al., 2002] и метасоматических явлений [Maury et al., 1992; Arai et al., 2003] указывает на то, что медленный подъем расплавов может осуществляться под влиянием обоих механизмов. Если подъем происходит по границам зерен, то рост омфацита, как показывают эксперименты, маловероятен. При медленном подъеме обособленных порций расплава вероятность образования омфацита возрастает.

Сегрегация расплава в мантии может происходить при его быстром подъеме в фокусированном потоке [Ortoleva et al., 1987; Aharonov et al., 1995; Spiegelman et al., 2001]. Модели такой миграции широко обсуждаются в научной литературе в связи с подъемом относительно маловязких базальтовых, кимберлитовых и карбонатитовых магм [Spence et al., 1987; Kelemen et al., 1995; Katz et al., 2006; Connolly et al., 2009; Батанова, Савельева, 2009]. Фокусирование потока может происходить при возникновении реакционной инфильтрационной нестабильности, при которой расплавы устремляются в пальце- и жилообразные области породы с повышенной пористостью. Последняя создается при растворении в магме локальных участков породы, по которым происходит саморазвитие транспортного процесса [Ortoleva et al., 1987; Connolly et al., 2009]. Взаимосвязь пористости и количества поступающего расплава способствует увеличению мощности каналов и даже созданию ветвящейся транспортной сети. С реакционной нестабильностью и локальными стрессовыми напряжениями часто связывают жилы дунитов и пироксенитов, наблюдаемые в гарцбургитах из офиолитовых комплексов [Kelemen et al., 1995; Савельева и др., 2008]. Отметим, что дунитовые и пироксенитовые жилы обычно рассматриваются как продукты изменения вмещающих пород под воздействием мигрирующих через них и впоследствии покинувших их магм. Тем не менее фокусированные потоки магмы в ультрамафитах можно наблюдать непосредственно в экспериментах [Daines, Kohlstedt, 1994], а также в природе - по микрожилам дацитового состава в ксенолитах лерцолитов и клинопироксенитов из базальтовых лав Северной Камчатки [Kepezhinskas et al., 1995, 1996]. Обратим внимание, что П. Кепежинскас с соавторами рассматривают клинопироксениты

${ }^{1}$ Кислые расплавы (см. рис. 1, таблицу), выплавленные из амфиболита при $P T$-условиях зоны субдукции, отвечают определению адакита по своей сути, даже при отсутствии аналитических данных по редкоземельным элементам, которые подтвердили бы свойственные для адакитов геохимические характеристики [например, La/Yb > 20]. 
как результат взаимодействия адакитов с ультраосновными породами мантии. Предполагаемая авторами температура этого взаимодействия в точности соответствует нашим экспериментам $\left(850 — 900{ }^{\circ} \mathrm{C}\right)$ при существенно более низком давлении (1.5 против 2.9 ГПа). Отсутствие омфацита в ксенолитах, вероятно, связано с недостаточным давлением для вхождения в структуру пироксена высокобарного жадеитового минала.

В некоторых глубинных ксенолитах вебстеритов из кимберлитовой тр. Обнаженная в Якутии, образованных при давлении $2.1-3.8$ ГПа и температуре $711-923{ }^{\circ} \mathrm{C}$, присутствует породообразующий омфацит [Taylor et al., 2003, table 2]. Примечательно, что в парагенезисе с омфацитом здесь находятся гранат и ортопироксен. Учитывая количественно минеральные соотношения, приведенные в статье, гранатовые вебстериты с омфацитом из ксенолитов можно называть ортопироксеновыми эклогитами. Ортопироксен в них, согласно петрографическому описанию, размещается между кристаллами граната, именно такие соотношения между минералами мы наблюдаем в оп. Sub73 при $900{ }^{\circ} \mathrm{C}$ и 2.9 ГПа (см. рис. 1, 2).

О природе омфацита в перидотитовых алмазах. Предложенный В. Вэнгом [Wang, 1998] многостадийный механизм образования включений омфацита в перидотитовых алмазах предполагает, что начальный рост алмаза происходил в эклогите, но впоследствии, попав под воздействие горячего мантийного плюма, алмаз переместился из эклогита в перидотит за счет селективного плавления эклогита и высокой плотности алмаза. Оказавшись таким образом в перидотитовом субстрате, алмаз продолжил свой рост в новой среде. С нашей точки зрения, предложенный механизм перемещения алмаза из одной породы в другую едва ли может обеспечить вывод алмаза даже за пределы эклогита, а уж тем более инкорпорацию его в твердый перидотит.

Более правдоподобной представляется гипотеза, предложенная в работе [Safonov et al., 2009], coгласно которой по эклогиту под воздействием глубинных жидкостей может развиваться перидотитовая ассоциация. Однако для этого превращения необходимо выполнение двух условий — присутствие щелочного хлоридно-карбонатного расплава и водно-хлоридного флюида. В первом случае (воздействие расплава) эклогитовый гранат замещается оливином, а омфацит останется неизменным. Во втором случае (воздействие флюида) ничего не происходит с гранатом, но омфацит лишается жадеитовой составляющей; в равновесии с таким клинопироксеном растут высококремнистая слюда и калиевый полевой шпат ([Nazzareni et al., 2008] и неопубликованные данные О.Г. Сафонова). Если такое комплексное флюидно-магматическое воздействие действительно имело место в природе, то в ядрах алмаза из апоэклогитового перидотита будут содержаться микровключения эклогитового, а в каймах — перидотитового парагенезиса [Гаранин и др., 1991; Wang, 1998].

Нам представляется, что при отсутствии хлоридно-карбонатных расплавов и водно-хлоридных флюидов образование включений смешанного парагенезиса в алмазах из перидотитового субстрата может происходить по следующему сценарию. Рассматриваемый в настоящей работе механизм образования омфацитсодержащих ассоциаций в эклогитах, пироксенитах и перидотитах на глубине около 90 км не исключает возможности их дальнейшего погружения в толще перидотитов до глубин стабильности алмаза за счет пластичного течения, вызванного сцеплением пород мантийного клина с субдуцирующей плитой. Там породы могут попасть под воздействие алмазообразующих (например, карбонатно-силикатных или карбонатно-водно-хлоридных) жидкостей, что приведет к образованию в них алмаза. Источник таких жидкостей находится в погружающихся или стагнирующих слэбах [Литасов, 2011; Palyanov et al., 2013]. Пространственная близость омфацита с перидотитом может обеспечить захват растущими кристаллами алмаза фрагментов любого из этих минералов. Отсутствие омфацита среди породообразующих минералов в перидотитовых ксенолитах может быть связано с его преобразованием под воздействием водно-хлоридных флюидов (вышеописанная модель О.Г. Сафонова) либо с ограниченностью его распространения в породах мантии.

\section{ЗАКЛЮЧЕНИЕ}

Экспериментальное моделирование взаимодействия между породами субдуцирующей коры и мантийного клина показало, что омфацит может образовываться не только при высокобарном метаморфизме субдуцирующих метабазитов и метапелитов, но и как реакционно-магматический минерал на границе кислого расплава с перидотитовым субстратом висячего крыла мантии. Экспериментальные результаты подтверждают возможность образования гранатовых вебстеритов и ортопироксеновых эклогитов за счет взаимодействия с перидотитами мантии кислых расплавов, выделившихся из субдуцирующей плиты [Taylor et al., 2003]. А вот для образования биминеральных эклогитов необходимы иные $P T$-условия и/или составы расплавов.

Важным условием роста магматического омфацита, ассоциирующего с флогопитом или гранатом и ортопироксеном, является сегрегация кислого расплава в оливинсодержащем субстрате. И, наоборот, при миграции кремнекислого расплава (и флюида) по границам зерен оливина омфацит не образуется, 
здесь растет ортопироксен, нередко с магнезитом, гранатом и флогопитом [Перчук и др., 2013]. Ортопироксеновые прожилки с гранатом и без него нередко встречаются в надсубдукционных перидотитах [Scambelluri et al., 2006; Bénard, Ionov, 2013].

Омфацит, образованный в перидотитовом субстрате при давлении ниже 3 ГПа, может достигнуть поля стабильности алмаза за счет нисходящего пластического течения вещества в висячем крыле мантии. Здесь под воздействием на омфацитсодержащую породу карбонатных (или комплексных) флюидов и расплавов, выделяющихся из слэба, может происходить рост алмаза с захватом окружающих минералов, в том числе омфацита. Впоследствии омфацитсодержащая ассоциация может либо раствориться в агрессивных водно-хлоридно-карбонатных жидкостях либо сохраниться в виде вебстеритовых или эклогитовых тел, описанных в ксенолитах тр. Обнаженная [Taylor et al., 2003].

Авторы благодарны В.О. Япаскурту за участие в проведении микрозондовых исследований, Н.В. Соболеву, В.С. Шацкому и О.Г. Сафонову за обсуждение результатов и сделанные замечания по статье.

Работа выполнена при поддержке РФФИ (грант 12-05-01093).

\section{ЛИТЕРАТУРА}

Батанова В.Г., Савельева Г.Н. Миграция расплавов в мантии под зонами спрединга и образование дунитов замещения: обзор проблемы // Геология и геофизика, 2009, т. 50 (9), с. 992-1012.

Гаранин В.К., Кудрявцева Г.П., Марфунин А.С., Михайличенко О.А. Включения в алмазе и алмазоносные породы. М., Изд-во Моск. ун-та, 1991, 240 с.

Гегузин Я.Е., Кружанов В.С. Движение жидкого включения в монокристалле в поле градиента напряжений // Кристаллография, 1979, т. 24, № 4, с. 866-867.

Добрецов Н.Л., Соболев Н.В., Шацкий В.С. Эклогиты и глаукофановые сланцы в складчатых областях. Новосибирск, Наука, 1989, 326 с.

Литасов К.Д. Физико-химические условия плавления мантии Земли в присутствии С-О-Н-флюида по экспериментальным данным // Геология и геофизика, 2011, т. 52 (5), с. 613-635.

Наумов В.Б., Коваленко В.И., Дорофеева В.А., Гирнис А.В., Ярмолюк В.В. Средний состав магматических расплавов главных геодинамических обстановок по данным изучения расплавных включений в минералах и закалочных стекол пород // Геохимия, 2010, № 12, с. 1266-1288.

Перчук А.Л., Давыдова В.В., Бурхард М., Мареш В.В., Шертл Х.П., Япаскурт В.О., Сафонов О.Г. Эффекты преобразования минеральных включений в гранате при высоком давлении: эксперимент и его приложение к карбонатно-силикатным породам Кокчетавского массива // Геология и геофизика, 2009, т. 50 (12), с. 1487-1505.

Перчук А.Л., Шур М.Ю., Япаскурт В.О., Подгорнова С.Т. Экспериментальное моделирование мантийного метасоматоза сопряженного с эклогитизацией корового вещества в зоне субдукции // Петрология, 2013, т. 21, № 6, с. 632-653.

Рагозин А.Л., Шацкий В.С., Зедгенизов Д.А., Митюхин С.И. Свидетельства эволюции среды кристаллизации алмазов в ксенолите эклогита из кимберлитовой трубки Удачная (Якутия) // ДАН, 2006, т. 407, № 5, с. $660-663$.

Савельева Г.Н. Габбро-ультрабазитовые комплексы офиолитов Урала и их аналоги в современной океанической коре. М., Наука, 1987, 246 с. (Тр. ГИН АН СССР, вып. 404).

Савельева Г.Н., Соболев А.В., Батанова В.Г., Суслов П.В., Брюгманн Г. Структура каналов течения расплавов в мантии // Геотектоника, 2008, № 6, с. 26-46.

Сафонов О.Г., Литвин Ю.А., Перчук Л.Л. Синтез омфацитов и особенности изоморфизма в клинопироксенах системы $\mathrm{CaMgSi}_{2} \mathrm{O}_{6}-\mathrm{NaAlSi}_{2} \mathrm{O}_{6}-\mathrm{KAlSi}_{2} \mathrm{O}_{6} / /$ Петрология, 2004, т. 12, № 1, с. 84-97.

Сафонов О.Г., Перчук Л.Л., Литвин Ю.А. Равновесие калийсодержащего клинопироксена с расплавом как модель для барометрии глубинных ассоциаций // Геология и геофизика, 2005, т. 46 (12), c. $1318-1334$.

Соболев В.С., Соболев Н.В., Лаврентьев Ю.Г. Включения в алмазе из алмазоносного эклогита // Докл. АН СССР, 1972, т. 207, № 1, с. 164-167.

Соболев Н.В. Глубинные включения в кимберлитах и проблема состава верхней мантии. Новосибирск, Наука, 1974, 264 с.

Соболев Н.В., Логвинова А.М., Ефимова Э.С. Сингенетические включения флогопита в алмазах кимберлитов: свидетельство роли летучих в образовании алмазов // Геология и геофизика, 2009, т. 50 (12), c. $1588-1606$.

Соболев Н.В., Соболев А.В., Томиленко А.А., Ковязин А.А., Батанова В.Г., Кузьмин Д.В. Парагенезис и сложная зональность вкрапленников оливина из неизмененного кимберлита трубки Удач- 
ная-Восточная (Якутия): связь с условиями образования и эволюцией кимберлита // Геология и геофизика, 2015, т. 56 (1-2), с. 337-360.

Aharonov E., Whitehead J.A., Kelemen P.B., Spiegelman M. Channeling instability of upwelling melt in the mantle // J. Geophys. Res., 1995, v. 100, p. 20433-20450.

Arai S., Ishimaru S. Insights into petrological characteristics of the lithosphere of mantle wedge beneath arcs through peridotite xenoliths: a review // J. Petrol., 2008, v. 49, p. 665-695.

Arai S., Ishimaru S., Okrugin V.M. Metasomatized harzburgite xenoliths from Avacha volcano as fragments of mantle wedge of the Kamchatka arc: Implication for the metasomatic agent // Island Arc, 2003, v. 12, p. $233-246$.

Bénard A., Ionov D.A. Melt- and fluid-rock interaction in supra-subduction lithospheric mantle: evidence from andesite-hosted veined peridotite xenoliths // J. Petrol., 2013, v. 54, p. 2339-2378.

Bodinier J.-L., Godard M. Orogenic, ophiolitic and abyssal peridotites // Treatise on Geochemistry, 2003, v. 2, p. 103-170.

Bulatov V.K., Brey G.P., Girnis A.V., Gerdes A., Höfer H.E. Carbonated sediment—peridotite interaction and melting at 7.5-12 GPa // Lithos, 2014, v. 200-201, p. 368-385.

Carroll M.R., Wyllie P.J. Experimental phase relations in the system tonalite-peridotite $\mathrm{H}_{2} \mathrm{O}$ at $15 \mathrm{~kb}$; Implications for assimilation and differentiation processes near the crust-mantle boundary // J. Petrol., 1989, v. 30, p. $1351-1382$.

Carswell D.A. Eclogites and eclogite facies: definitions and classification // Eclogite facies rocks / Ed. D.A. Carswell. 1990, Glasgow, London, Blackie, p. 1-13.

Castillo P.R. An overview of adakite petrogenesis // Chinese Sci. Bull., 2006, v. 51, p. 257-268.

Coleman R.G., Lee D.E., Brannock W.W. Eclogites and eclogites: their difference and similarities // Bull. Geol. Soc. Amer., 1965, v. 76, p. 483-508.

Connolly J.A.D., Schmidt M.W., Solferino G., Bagdassarov N. Permeability of asthenospheric mantle and melt extraction rates at mid-ocean ridges // Nature, 2009, v. 462, p. 209-212.

Daines M.J., Kohlstedt D.L. The transition from porous to channelized flow due to melt/rock reaction during melt migration // Geophys. Res. Lett., 1994, v. 21, p. 145-148.

Davies H.J., Stevenson D.J. Physical model of source region of subduction zone volcanics // J. Geophys. Res., 1992, v. 97, p. 2037-2070.

Fountain D.M., Christensen N.I. Composition of the continental crust and upper mantle: A review // Geophysical framework of the continental United States. Geol. Soc. Am. Memoir 172 / Eds. L.C. Parker, W.D. Mooney. Boulder, Colorado, 1989, p. 711-742.

Fumagalli P., Poli S. Experimentally determined phase relations in hydrous peridotites to $6.5 \mathrm{GPa}$ and their consequences on the dynamics of subduction zones // J. Petrol., 2005, v. 46, p. 555-578.

Gerya T. Future directions in subduction modeling // J. Geodynam., 2011, v. 52, p. 344-378.

Gerya T.V., Stockhert B., Perchuk A.L. Exhumation of high-pressure metamorphic rocks in subduction channel: a numerical simulation // Tectonics, 2002, v. 21, p. 6-1-6-19.

Grove T.L., Till C.B., Krawczynski M.J. The Role of $\mathrm{H}_{2} \mathrm{O}$ in subduction zone magmatism // Ann. Rev. Earth Planet. Sci., 2012, v. 40, p. 413-439.

Hacker B.R., Abers G.A., Peacock S.M. Subduction factory: 1. Theoretical mineralogy, density, seismic wave speeds, and $\mathrm{H}_{2} \mathrm{O}$ content // J. Geophys. Res., 2003, v. 108, 2029.

Hammouda T., Laporte D. Ultrafast mantle impregnation by carbonatite melts // Geology, 2000, v. 28, p. $283-285$.

Hermann J., Spandler C.J. Sediment melts at sub-arc depths: an experimental study // J. Petrol., 2008, v. 49, p. $717-740$.

Jacob D.E. Nature and origin of eclogite xenoliths from kimberlites // Lithos, 2004, v. 77, p. 295-316.

Katz R.F., Spiegelman M., Holtzman B. The dynamics of melt and shear localization in partially molten aggregates // Nature, 2006, v. 442, p. 676-679.

Kelemen P.B., Whitehead J.A., Aharonov E., Jordahl K.A. Experiments on flow focusing in soluble porous media, with applications to melt extraction from the mantle // J. Geophys. Res., 1995, v. 100, p. 475496.

Kepezhinskas P.K., Defant M.J., Drummond M.S. Na metasomatism in the island-arc mantle by slab melt - peridotite interaction: evidence from mantle xenoliths in the North Kamchatka arc // J. Petrol., 1995, v. 36, p. $1505-1527$.

Kepezhinskas P.K., Defant M.J., Drummond M.S. Progressive enrichment of island arc mantle by melt-peridotite interaction inferred from Kamchatka xenoliths // Geochim. Cosmochim. Acta, 1996, v. 60, p. $1217-1229$. 
Kessel R., Ulmer P., Pettke T., Schmidt M.W., Thompson A.B. The water-basalt system at 4 to 6 GPa: phase relations and second critical endpoint in a K-free eclogite at 700 to $1400{ }^{\circ} \mathrm{C} / /$ Earth Planet. Sci. Lett., 2005 , v. 237, p. 873-892.

Kohlstedt D.L., Holtzman B.K. Shearing melt out of the Earth: An experimentalist's perspective on the influence of deformation on melt extraction // Ann. Rev. Earth Planet. Sci., 2009, v. 37, p. 561—593.

Krogh E.J., Carswell D.A. HP and UHP eclogites and garnet peridotites in the Scandinavian Caledonides // Ultrahigh pressure metamorphism / Eds. R.G. Coleman, X. Wang. Cambridge, Cambridge Univ. Press, 1995, p. $244-298$.

Martin H., Smithies R.H., Rapp R., Moyen J.-F., Champion D. An overview of adakite, tonalite-trondhjemite-granodiorite (TTG), and sanukitoid: relationships and some implications for crustal evolution // Lithos, 2005, v. 79, p. $1-24$.

Maury R.C., Defant M.J., Joron J.L. Metasomatism of the sub-arc mantle inferred from trace elements in Philippine xenoliths // Nature, 1992, v. 360, p. 661-663.

Mibe K., Kawamoto T., Matsukage N.K., Fei Y., Ono Sh. Slab melting versus slab dehydration in subduction-zone magmatism // PNAS, 2011, v. 108, p. 8177-8182.

Nazzareni S., Comodi P., Bindi L., Safonov O.G., Litvin Yu.A., Perchuk L.L. Synthetic hypersilicic Cl-bearing mica in the phlogopite-celadonite join: a multimethodical characterization of the missing link between di- and tri-octahedral micas at high pressures // Amer. Mineral., 2008, v. 93, p. 1429-1436.

Nicolas A., Christensen N.I. Formation of anisotropy in upper mantle peridotites: a review // Composition, structure, and dynamics of lithosphere-asthenosphere system. Geodyn. Ser. / Eds. K. Fuchs, C. Froidevaux. AGU, Washington, D.C., 1987, v. 16, p. 111-123.

Ohtani E. Water in the mantle // Elements, 2005, v. 1, p. 25-30.

Ortoleva P., Chadam J., Merino E., Sen A. Geochemical self-organization; II. The reactive-infiltration instability // Amer. J. Sci., 1987, v. 287, p. 1008-1040.

Palyanov Yu.N., Bataleva Yu.V., Sokol A.G., Borzdov Yu.M., Kupriyanov I.N., Reutsky V.N., Sobolev N.V. Mantle - slab interaction and redox mechanism of diamond formation // PNAS, 2013, v. 110, p. $20408-20413$.

Peacock S.M. Fluid processes in subduction zones // Science, 1990, v. 248, p. 329-337.

Peacock S.M., Wang K. Seismic consequences of warm versus cool subduction zone metamorphism: examples from northeast and southwest Japan // Science, 1999, v. 286, p. 937—941.

Peacock S.M., Rushmer T., Thompson A.B. Partial melting of subducting oceanic crust // Earth Planet. Sci. Lett., 1994, v. 121, p. 227-244.

Peacock S.M., van Keken P.E., Holloway S.D., Hacker B.R., Abers G.A., Fergason R.L. Thermal structure of the Costa Rica - Nicaragua subduction zone // Phys. Earth Planet. Int., 2005, v. 149, p. 187-200.

Pearson D.G., Canil D., Shirey S.B. Mantle samples included in volcanic rocks: xenoliths and diamonds // Treatise on geochemistry, Amsterdam, Elsevier, 2003, v. 2, p. 172-270.

Perchuk L.L., Safonov O.G., Yapaskurt V.O., Barton J.M. Jr. Crystal-melt equilibria involving potassium-bearing clinopyroxene as indicator of mantle-derived ultrahigh-potassic liquids: an analytical review // Lithos, 2002, v. 60, p. 89-111.

235.

Poli S., Schmidt M. Petrology of subducted slabs // Ann. Rev. Earth Planet. Sci., 2002, v. 30, p. $207-$

Portnyagin M., Hoernle K., Plechov P., Mironov N., Khubunaya S. Constraints on mantle melting and composition and nature of slab components in volcanic arcs from volatiles $\left(\mathrm{H}_{2} \mathrm{O}, \mathrm{S}, \mathrm{Cl}, \mathrm{F}\right)$ and trace elements in melt inclusions from the Kamchatka Arc // Earth Planet. Sci. Lett., 2007, v. 255, p. 53-69.

Rapp R.P., Shimizu N., Norman M.D., Applegate G.S. Reaction between slab-derived melts and peridotite in the mantle wedge: experimental constraints at $3.8 \mathrm{GPa} / /$ Chem. Geol., 1999, v. 160, p. 335-356.

Riley G.N., Kohlstedt D.L. Kinetics of melt migration in upper mantle-type rocks // Earth Planet. Sci. Lett., 1991, v. 105, p. 500-521.

Riley R., Kohlstedt D.L., Richter F.M. Melt migration in a silicate liquid-olivine system: An experimental test of compaction theory // Geophys. Res. Lett., 1990, v. 17, p. 2101-2104.

Safonov N.G., Chertkova N.V., Perchuk L.L., Litvin Yu.A. Experimental model for alkalic chloriderich liquids in the upper mantle // Lithos, 2009, v. 112S, p. 260-273.

Scambelluri M., Hermann J., Morten L., Rampone E. Melt- versus fluid-induced metasomatism in spinel to garnet wedge peridotites (Ulten Zone, Eastern Italian Alps): clues from trace element and Li abundances // Contr. Miner. Petrol., 2006, v. 151, p. 372-394.

Schiano P. Primitive mantle magmas recorded as silicate melt inclusions in igneous minerals // Earth Sci. Rev., 2003, v. 63, p. 121-144. 
Schmidt M.W., Poli S. Experimentally based water budgets for dehydrating slabs and consequences for arc magma generation // Earth Planet. Sci. Lett., 1998, v. 163, p. 361-379.

Shatskiy A., Litasov K.D., Borzdov Y.M., Katsura T., Yamazaki D., Ohtani E. Silicate diffusion in alkali-carbonatite and hydrous melts at 16.5 and $24 \mathrm{GPa}$ : implication for the melt transport by dissolution-precipitation in the transition zone and uppermost lower mantle // Phys. Earth Planet. Int., 2013, v. 225, p. 1-11.

Shatsky V., Ragozin A., Zedgenizov D., Mityukhin S. Evidence for multistage evolution in a xenolith of diamond-bearing eclogite from the Udachnaya kimberlite pipe // Lithos, 2008, v. 105, p. 289-300.

Shimizu N. Potassium contents of synthetic clinopyroxenes at high pressures and temperatures // Earth Planet. Sci. Lett., 1971, v. 11, p. 374-380.

Shirey S.B., Cartigny P., Frost D.J., Keshav S., Nestola F., Nimis P., Pearson D.G., Sobolev N.V., Walter M.J. Diamonds and the geology of mantle carbon // Carbon in Earth. Rev. Miner. Geochem., 2013, v. 75 , p. $355-421$.

Smyth J.R. Hydrogen in High Pressure Silicate and Oxide Mineral Structures // Rev. Miner. Geochem., 2006, v. 62, p. 85-115.

Sobolev N.V., Sobolev V.N., Snyder G.A., Yefimova E.S., Taylor L.A. Significance of eclogitic and related parageneses of natural diamonds // Int. Geol. Rev., 1999, v. 41, № 2, p. 129-140.

Spence D.A., Sharp P.W., Turcotte D.L. Buoyancy-driven crack propagation: a mechanism for magma migration // J. Fluid Mech., 1987, v. 174, p. 135-153.

Spiegelman M., Kelemen P.B., Aharonov E. Causes and consequences of flow organization during melt transport: the reaction infiltration instability in compactable media // J. Geophys. Res.-Solid Earth, 2001, v. 106, p. $2061-2077$.

Stachel T., Harris J.W. The origin of cratonic diamonds: constraints from mineral inclusions // Ore Geol. Rev., 2008, v. 34, p. 5-32.

Syracuse E.M., van Keken P.E., Abers G.A. The global range of subduction zone thermal models // Phys. Earth Planet. Int., 2010, v. 51, p. 1761-1782.

Tatsumi Y. Slab melting: Its role in continental crust formation and mantle evolution // Geophys. Res. Lett., 2000, v. 27, p. 3941-3944.

Taylor L.A., Snyder G.A., Keller R., Remley D.A., Anand M., Wiesli R., Valley J., Sobolev N.V. Petrogenesis of group A eclogites and websterites: evidence from the Obnazhennaya kimberlite, Yakutia // Contr. Miner. Petrol., 2003, v. 145, p. 424-443.

van Keken P.E., Hacker B.R., Syracuse E.M., Abers G.A. Subduction factory 4: depth-dependent flux of $\mathrm{H}_{2} \mathrm{O}$ from slabs worldwide // J. Geophys. Res., 2011, v. 116, B01401.

Viljoen K.S., Schulze D.J., Quadling D.J. Contrasting group I and group II eclogite xenolith petrogenesis: petrological, trace element and isotopic evidence from eclogite, garnet-websterite and alkremite xenoliths in the Kaalvallei Kimberlite, South Africa // J. Petrol., 2005, v. 46, p. 2059-2090.

Wang W. Formation of diamond with mineral inclusions of «mixed» eclogite and peridotite paragenesis // Earth Planet. Sci. Lett., 1998, v. 160, p. 831-843.

Watson E.B. Melt infiltration and magma evolution // Geology, 1982, v. 10, p. 236-240. 